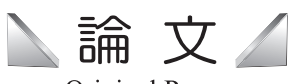

Original Paper

\section{電解酸化一液体膜輸送ハイブリッド分離法によるセリウムを 主とした希土類元素の相互分離に関する基礎研究 *}

\title{
A Basic Study for Cerium Separation from Rare-earth Element by Hybrid Separation System
}

by Hiroki KANEKO ${ }^{\mathrm{a}}$, Tsuyoshi ARAI ${ }^{\mathrm{b}}$, Katsuhisa NAGAYAMA ${ }^{\mathrm{c}}$ and Ryo INOUE $^{\mathrm{a}}$

\begin{abstract}
a. Graduate student, Material Engineering, Shibaura Institute of Technology Graduate School of Engineering (*Corresponding author E-mail: m209016@sic.shibaura-it.ac.jp)

b. Assistant Professor, Material Engineering, Shibaura Institute of Technology

c. Professor, Material Engineering, Shibaura Institute of Technology
\end{abstract}

\begin{abstract}
We have been investigating the development of the hybrid-separation system for mutual separation rare-earth element in a number of rare-earth elements. The hybrid-separation systems use electrolytic oxidation and liquid membrane supported TBP techniques. In the present work, electrolytic oxidation behaviors of Ce (III) and Nd (III) as simple condition were investigated with the flow type electrolytic cell. In this work, it was found that Ce (III) can be effectively oxidized to Ce (IV) using the flow type electrolytic cell. Furthermore, separation behavior of $\mathrm{Ce}$ from $\mathrm{Nd}$ in medium nitric acid solutions after the electrolytic oxidation were investigated using the liquid membrane supported TBP. In this study, it was obtained that Ce (IV) can be separated from Nd (III) by this separation system in nitric acid medium.
\end{abstract}

KEY WORDS: Ce (IV), Flow Type Electrolytic Cell, Elctrolytic Oxidation, Membrane Separation, Hybrid Separation System

\section{1. 緒言}

我が国の産業社会を支える電子製品の多くには希土類元素等の 希少金属が多く用いられている。希土類元素は世界の産出量の約 $90 \%$ が中国に埋蔵されており，中国の経済成長に伴い需給バラ ンスの逼迫が懸念されている。そのため，近年，新しい鉱物資源 として期待されている都市鉱山より, 希土類元素の分離回収が望 まれる。希土類元素の分離回収技術についてはイオン交換法や溶 媒抽出法等の様々な報告が挙げられているが, 化学的性質が類似 しているため, 新規抽出剤の開発費用や分離工程が複雑で廃液の 肥大化が問題となっている ${ }^{1-4)}$ 。

そこで本研究では, 原子価の変化による吸着特性の違いに着目 した。一般的に金属イオンの原子価が変化することで, 溶液中 の金属イオンと対イオンとの錯体が変化するため抽出, 吸着挙 動が大きく変化する。これまでに希土類元素の分離に関する研 究は, ジ (2-エチルヘキシル) リン酸 (Di (2-ethlhexyl) phosphoric acid;DEHPA) やリン酸トリブチル (Tri-n-butyl phosphate;TBP) 等の 抽出剂を用いた事例が報告されている ${ }^{3,5,6)}$ 。しかし，これらの

*2010 年 11 月 11 日受付 2011 年 6 月 29 日受理

1. 芝浦工業大学大学院生工学研究科材料工学専攻

2. 正会員芝浦工業大学助教工学部材料工学科

3. 芝浦工業大学教授 工学部材料工学科

[ 著者連絡先] FAX: 03-5859-8101 (芝浦工業大学・金子) E-mail: m209016@sic.shibaura-it.ac.jp

キーワード : Ce (IV), フロー型電解セル, 電解酸化, 膜分離, ハイブリッ ド分離法
方法は, 多様な添加剤や分離工程を増やすこととなり, 二次廃棄 物の増加に繋がる可能性が懸念される。そこで希土類元素の分離 場に原子価調整反応と抽出反応を介在させ, 同時にそれらの反応 を誘起させる分離法 ( ハイブリッド分離法 ) の適用性について検 討を行った。これまでに, 希土類元素の分離法として, フロー型 電解セルを用いて電気化学的に原子価調整を行った金属溶液を調 整し，イオン交換樹脂を用いたカラム分離についての報告がされ ている7)。また, 同様に電気化学的にアクチノイド元素の原子 価を調整し, その後従来の溶媒抽出法としてミキサーセトラによ る分離を行った報告がされている ${ }^{8)}$ 。しかし，何れの報告にお いても, 原子価調整を行った後, 分離工程に送液され分離が行わ れる。そのため, 分離場における再還元の可能性, プロセスの複 雑化による廃棄物発生の肥大化が予測される。そこで本研究では, 抽出剂を含浸させた液体膜を介した液体膜輸送法を用い, 原子価 調整と液体膜分離を同時に行うハイブリッド分離法を提案した。 ハイブリッド分離法は従来技術と比較し, 多量の有機溶媒を使用 せず, 定電位電解による原子価調整により添加剤の低減, 分離プ ロセスの簡素化が期待できるといった利点がある。本研究では, 希土類元素の中でも原子価の調整が可能な $\mathrm{Ce}$ と, 原子価が比較 的安定している $\mathrm{Nd}$ 用いて試験を行った。Ceの分離方法として, Ce イオンの酸化状態の変化を利用し, Ce (IV) の沈殿・晶析を利 用する分離法も報告されているが, 先述した本法の利点が期待で きる9)。電気化学による原子価調整にはフロー型電解セルを用い, $\mathrm{Ce}$ (III) から Ce (IV) への電解酸化挙動を検討した。また, 液体膜 


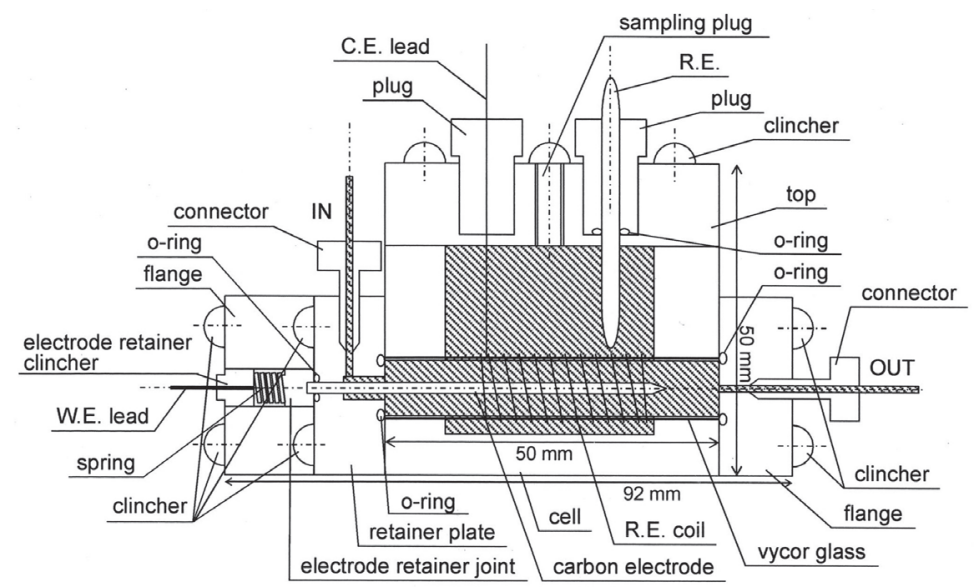

Fig.1 Schematic diagram of the flow type electrolysis apparatus. ${ }^{15)}$
本研究におけるフロー型電解セルを用いた電解酸 化試験は，電解液として $10 \mathrm{mmol} / \mathrm{dm}^{3}$ ( 以降 $\mathrm{mol} / \mathrm{dm}^{3}$ を $\mathrm{M}$ と略記) の Ce (III) を含む $0.1 \sim 7 \mathrm{M}$ の硝酸水溶 液を用いた。電解液はペリスタリックポンプを用い て流速 $1 \mathrm{~cm}^{3} / \mathrm{min}$ でフロー型電解セルに通液し, ポテ ンショ/ガルバノスタット (北斗電工製, HA-502G) を用いて所定の電位により定電位電解酸化を行った。 電解酸化時間は最大 50 分とし, フロー型電解セルの 出口側より流出する溶液を 5 分ごとに分画採取した。 本試験で得られた電解溶液中の Ce (IV) 濃度は, 酸化 還元滴定法により測定した ${ }^{14)}$ 。また, Ce 全濃度は キシレノールオレンジを発色剂に用い, 紫外・可視 分光光度計 (日本分光 (株) 製, V-630 型) により 570 $\mathrm{nm}$ の波長で定量分析に資した。

\section{$2 \cdot 2$ 液体膜分離試験}

$2 \cdot 2 \cdot 1$ 溶媒抽出及び逆抽出試験 本研究て

輸送による各元素の抽出挙動について詳細に検討を加えた。さら に, 電気化学法と液体膜輸送法をシステム化したハイブリッド分 離試験装置を作製し, 本装置の分離性能試験を行い, 希土類元素 の相互分離への適用性について検討したので報告する。

\section{2. 実 験 方 法}

\section{$2 \cdot 1$ セリウムの電解試験}

$2 \cdot 1 \cdot 1$ 試験溶液の調製本研究では, 水溶液中における 原子価の状態を考慮することが重要である。式 (1), 式 (2) に示 すように, $\mathrm{Ce}$ は希土類元素の中でも特異的に 4 価をとることが 知られている10)。

$$
\begin{aligned}
& \mathrm{Ce}^{4+}+\mathrm{e}=\mathrm{Ce}^{3+} \\
& E^{0}=1.72 \text { (vs.N.H.E.) }
\end{aligned}
$$

$$
\mathrm{CeO}_{2}+4 \mathrm{H}^{+}+\mathrm{e}=\mathrm{Ce}^{3+}+2 \mathrm{H}_{2} \mathrm{O}
$$$$
E^{0}=1.4 \text { (vs.N.H.E.) }
$$

一方, Nd は式 (3) に示すように 3 価が極めて安定であり, 水 溶液中において原子価変化は生じないものと推測される。

$$
\begin{aligned}
& \mathrm{Nd}^{3+}+3 \mathrm{e}=\mathrm{Nd} \\
& E^{0}=-2.32 \text { (vs.N.H.E.) }
\end{aligned}
$$

本研究では Ce (III) に硝酸セリウム, Ce (IV) に水酸化セリウム を用いた。また, Nd (III) には硝酸ネオジムを用いた。何れの試 薬も所定濃度の硝酸溶液に溶解して調製し試験に用いた。

$2 \cdot 1 \cdot 2 \mathrm{Ce}(\mathrm{III})$ から Ce (IV) への電解酸化試験 硝酸水溶 液中における $\mathrm{Ce}$ (III) から Ce (IV) への電解酸化試験は, 北斗電 工 ( 株) 製のフロー型電解セル (HX-201) を用いて行った。フロー 型電解セルの概略図を Fig. 1 に示す。フロー型電解セルは, 隔 膜に内径 $8 \mathrm{~mm}$, 外径 $10 \mathrm{~mm}$, 長さ $50 \mathrm{~mm}$ のバイコールガラス 管を用い, その中に直径約 $10 \mu \mathrm{m}$ のグラッシーカーボン繊維を 密に充填した作用電極を有し, 対極としてバイコールガラス管 の外周に白金線をコイル状に巻くことで構成される。参照電極に は, 飽和 $\mathrm{Ag} / \mathrm{AgCl}$ 電極を用いた。隔膜であるバイコールガラス は, 平均細孔径が約 $4.5 \mathrm{~nm}$ の多孔性シリカガラス材であり, 作用 電極中のグラッシーカーボン繊維への電気的接続は, グラッシー カーボン棒を圧入することで電気的な導通が図られている ${ }^{11-13)}$ 。
は, 液体膜に用いる抽出剤の基礎的な抽出挙動を検討するために 溶媒抽出試験を行った。溶媒抽出試験では, TBP をドデカンで $1: 1$ に希勫し抽出剤として調製した。抽出溶液は Ce (IV)， Ce (III)， $\mathrm{Nd}$ (III) を各々 $10 \mathrm{mM}$ 含む $1 \sim 10 \mathrm{M}$ 硝酸水溶液を用いた。溶媒 抽出試験は, 金属毎に TBP と抽出溶液を $4 \mathrm{~cm}^{3}$ ずつ遠沈管に入 れ 30 分間振盪させた。その後, 遠沈管を静置し, 水相のみを取 り出し, 遠心分離器で油分を完全に除去した後, 水相の金属濃度 を測定した。得られた濃度から式 (4) を用いて抽出分配係数 $K d$ を算出した。 $\left[S_{1}\right]_{O}$ は有機相中の金属濃度, $\left[S_{1}\right]_{w}$ は水相中の金属 濃度を示す。また, 得られた抽出分配係数より Ce (IV) に対する 各元素の分離係数 $\alpha$ を式(5)より算出した。

$$
\begin{aligned}
& K d=\left[S_{1}\right]_{o} /\left[S_{1}\right]_{w} \\
& \alpha=K d_{C e(I V)} / K d_{\text {Metal }}
\end{aligned}
$$

$\mathrm{TBP}$ 抽出剂に抽出された金属イオンを水相へ回収する為に, 逆抽出試験を行った。本試験では予め Ce (IV) を TBP に抽出させ た後, 水相を遠心分離器により除去し, 油相に $0.01 \sim 3 \mathrm{M}$ の硝 酸水溶液を各々 $2 \mathrm{~cm}^{3}$ 注入し抽出試験同様に 10 分間振盪させた。 その後, 溶媒抽出試験同様に水相の金属濃度を測定した。得られ た濃度より，式 (6) を用いて回収率 R (\%) を算出した。ここで, $C_{0}$ は抽出前金属濃度 $(\mathrm{mM}), C_{\mathrm{S} 1}$ は抽出試験後の水相中金属濃度 $(\mathrm{mM}), C_{\mathrm{S} 2}$ は逆抽出試験後の水相中金属濃度 $(\mathrm{mM})$ を示寸。

$$
R=C_{\mathrm{S} 2} \times 100 /\left(C_{0}-C_{\mathrm{S} 1}\right)
$$

$2 \cdot 2 \cdot 2$ 液体膜分離試験液体膜分離試験では，透明アク リル樹脂製のセルを二槽連結した液体膜分離セルを用いた。液体 膜分離セルの概略図を Fig. 2 に示す。液体膜分離セルは, 供給槽 と回収槽で構成され, 二槽間には厚さ $80 \mu \mathrm{m}$, 平均孔径 $0.45 \mu \mathrm{m}$ のテフロン膜に TBP を含浸させた液体膜を有する構造を呈する。 供給槽には $10 \mathrm{mM}$ の各金属元素を含む硝酸水溶液を注入し, 回 収槽には逆抽出試験で得られた回収率の高い硝酸溶液を注入し, 何れの槽もそれぞれ擋拌させて分離試験に資した。所定時間毎に 供給・回収槽の各々の金属濃度を測定した。

\section{$2 \cdot 3$ ハイブリッド分離試験}

本研究ではフロー型電解セルと液体膜分離セルを組み合わせた ハイブリッド分離試験装置を作製した。Fig. 3 に液体膜分離試験 装置の概略図を示す。本試験装置は, 液体膜分離セルの供給槽中 の Ce (III) をフロー型電解セルにより電解酸化を行い, 同時に電 解酸化された Ce (IV) を即時に液体膜を介して回収槽に輸送する。 


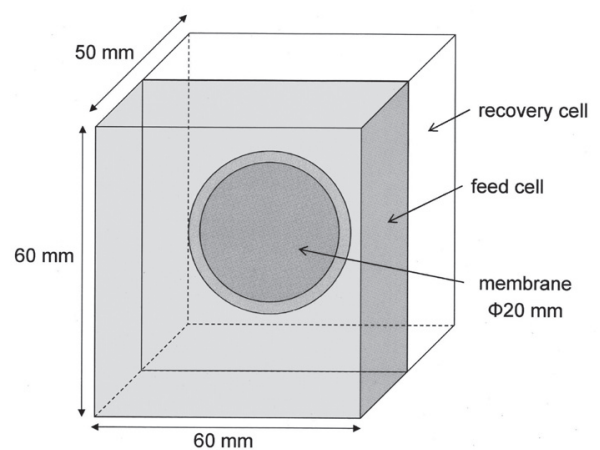

Fig.2 Schematic diagram of liquid membrane separation apparatus.

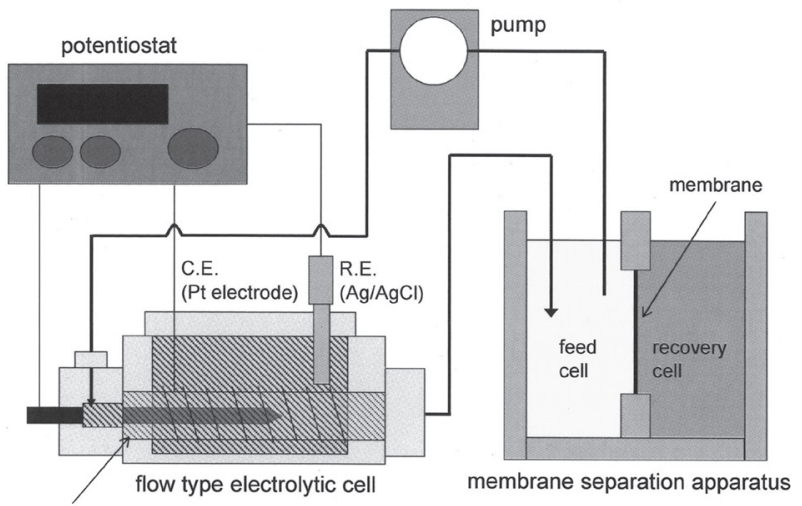

W.E. (glassy carbon electrode)

Fig.3 Schematic diagram of hybrid separation system.

フロー型電解セルと液体膜分離セル間は内径約 $0.8 \mathrm{~mm}$ のテフロ ンチューブで連結されており, 電解酸化された Ce (IV) は隣接し た液体膜分離セル内に即座に供給される。また, 電解酸化された $\mathrm{Ce}$ (IV) はフロー型電解セルと液体膜分離セル内を循環している ため, 一度電解酸化された Ce (IV) は装置間で還元され難く, 還 元反応を起こすより早く分離することが可能である。

本試験では, 供給槽に抽出溶液を注入し, 抽出液をペリスタリッ クポンプでフロー型電解セル内を循環させ，ポテンショガルバノ スタットにより所定の電位を付与しながら分離試験を実施した。 液体膜分離セル内は, 擋拌子により槽内を十分擋拌混合させなが ら試験を行い, 所定時間毎に各槽の金属濃度を測定し, 本分離装 置の性能を評価した。

\section{3. 結果及び考察}

\section{$3 \cdot 1$ フロー型電解セルによる Ce (III) の電解酸化試験}

\section{(1) 電解電位依存性の検討}

本研究では, 硝酸水溶液中における Ce (III) / Ce (IV) の電解酸 化反応を検討するために電解電位を変化させて試験を行った。

Fig. 4 に $3 \mathrm{M}$ 硝酸水溶液中における電解電位の違いによる Ce (III) の電解酸化試験結果を示寸。

Fig. 4 より電解電位の上昇に伴い Ce (IV) 収率が増加すること が確認され, $1.8 \mathrm{~V}$ (vs. $\mathrm{Ag} / \mathrm{AgCl}$ ) で $90 \%$ 以上の Ce (IV) 収率を得 ることができた。 $\mathrm{Ce}^{3+} / \mathrm{Ce}^{4+}$ の標準酸化還元電位 $E^{0}$ は, 式 (4) で 示したように+1.72 V (vs.NHE) であり, 本実験で得られた +1.81 $\mathrm{V}(\mathrm{vs} . \mathrm{Ag} / \mathrm{AgCl})$ と良好な一致が確認された ${ }^{16)}$ 。また, Fig. 5 に サイクリックボルタンメトリーによる $3 \mathrm{M}$ 硝酸水溶液中での $\mathrm{Ce}$ の電流密度一電位曲線を示す。

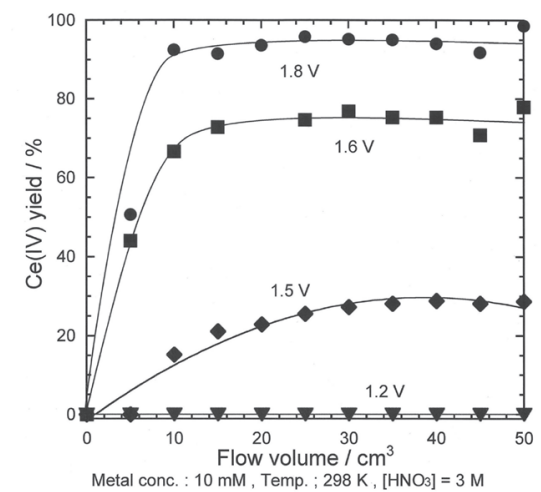

Flow speed : $1 \mathrm{~cm}^{3} / \mathrm{s}$

Fig.4 Correlation diagram for Ce (IV) yield and various potentials.

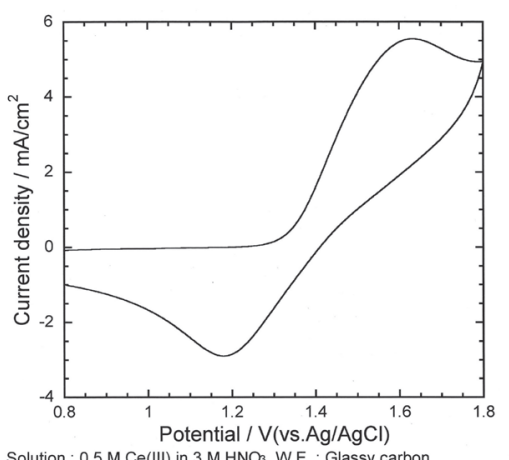

C.E. : Platinum, R.E. : Ag/AgCl. Scan rate $100 \mathrm{mV} / \mathrm{s}$, Temp. : $298 \mathrm{~K}$
Colution : $0.5 \mathrm{M} \mathrm{Ce}(\mathrm{III})$ in $\mathrm{M} \mathrm{HNO}$, W.E. : Glassy carbon

Fig.5 Cyclic voltammogram of Ce (III) in $3 \mathrm{M} \mathrm{HNO}_{3}$ solution.

Table 1 Assay data of electrolytic oxidation in various potentials.

\begin{tabular}{c|c|c|c}
\hline potential (V) & average current (A) & $\mathrm{Ce}(\mathrm{IV})$ yield (\%) & current efficiency (\%) \\
\hline 1.2 & 0.00076 & 0 & 0 \\
\hline 1.5 & 0.01376 & 26.4 & 61.6 \\
\hline 1.6 & 0.03436 & 75.9 & 71.0 \\
\hline 1.8 & 0.08495 & 94.3 & 35.6 \\
\hline
\end{tabular}

Fig. 5 より, $3 \mathrm{M}$ 硝酸水溶液中で $\mathrm{E}_{\mathrm{pa}}$ は $1.63 \mathrm{~V}$ (vs.Ag/ $\left.\mathrm{AgCl}\right)$ となっ た。飽和 $\mathrm{KCl}$ 中の $\mathrm{Ag} / \mathrm{AgCl}$ 電極は N.H.E. に対して $+0.197 \mathrm{~V}$ をと る為, Fig. 5 よりも Ce (IV) への電解酸化電位は適当であると考 えられる。これらの結果よりフロー型電解セルを用いることで定 常的に Ce (IV) を得られることが確認された。

Fig. 4 で得られた試験結果から電流効率を算出した。その結果 を Table 1 に示す。Table 1 より, 電解電位の上昇に伴い, 平均電 流值, 平均 Ce (IV) 収率共に増加することが確認された。しかし, 電流効率は $1.6 \mathrm{~V}$ (vs. $\mathrm{Ag} / \mathrm{AgCl}$ ) で最も高く, $\mathrm{Ce}$ (IV) 収率が最も高 い $1.8 \mathrm{~V}$ (vs. $\mathrm{Ag} / \mathrm{AgCl})$ では約 $35.6 \%$ と顕著に低下した。これは, 水の分解反応や電極の劣化反応等に起因するものと考えられた。 電流効率は, このプロセスの工業的な使用を検討する上では極め て重要な因子である。今後, 更に電流効率の低下要因を検討寸る 必要があると考えられる。

\section{(2) 硝酸濃度変化による Ce (III) の電解酸化試験}

本研究で提案するハイブリッド分離法を実際の工業的利用を想 定した場合, 溶解液である硝酸水溶液の濃度の影響を考える必要 がある。そこで本研究では, 硝酸濃度の違いによる Ce (III) の電 解酸化試験を行った。各硝酸濃度における Ce (III) の電解酸化試 


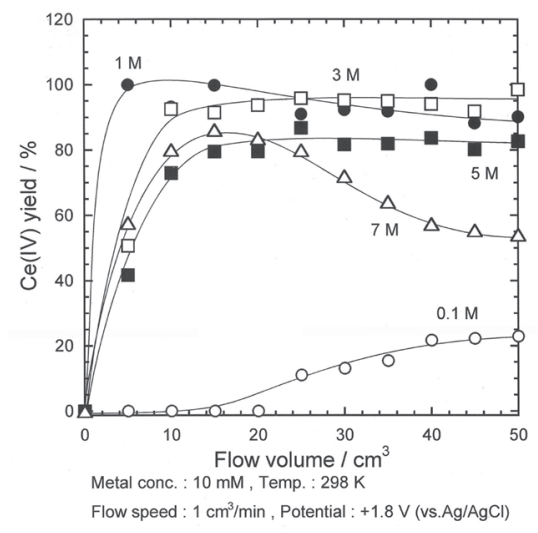

Fig.6 Correlation diagram for Ce (IV) yield and various $\mathrm{HNO}_{3}$ concentrations.

験結果を Fig. 6 に示す。また，本試験では上記の試験結果で最も $\mathrm{Ce}$ (IV) 収率の高かった $1.8 \mathrm{~V}$ (vs. $\mathrm{Ag} / \mathrm{AgCl})$ で定電位電解酸化試験 に資した。

Fig. 6 より, $1 \mathrm{M}$ 以上の硝酸水溶液中において Ce (III) は, 比較 的良好に Ce (IV) に電解酸化されることが確認された。特に 1,3 M 硝酸水溶液中では, Ce (IV) 収率がほぼ $100 \%$ になることが確 認された。また， $5 \mathrm{M}$ の硝酸水溶液中では， Ce (IV) の収率が 80 $\%$ に, $7 \mathrm{M}$ の硝酸水溶液中では電解酸化を開始して約 70 分後に 収率が大きく低下することが確認された。これは, 高濃度の硝酸 水溶液中における電解試験により, 作用極のグラッシーカーボン 電極の劣化が原因であると推察された。そこで, 電解酸化試験後 のグラッシーカーボン電極表面を走査型電子顕微鏡 (SEM) によ り観察した。Fig. 7 にSEM 写真を示す。

Fig. 7 より, 繊維表面が崩壞している様子が観察された。これ は, 繊維表面上で硝酸イオンが硝酸ラジカルへと電極酸化された ことに起因すると考えられる。そのため, 硝酸濃度の増加及び Ce (IV) 生成に伴う酸化力がグラッシーカーボン電極表面の酸化 劣化を誘引する可能性が示唆された。一方, $0.1 \mathrm{M}$ 硝酸溶液中では, Ce (IV) の収率が $30 \%$ 未満となった。これは, 低濃度の硝酸溶液 中では, Ce (IV) が不安定であり Ce (III) へ再還元したことに起因 するものと推察された。

Table 2 に各硝酸濃度におけるそれぞれでの電位に対する電流 や, Ce (IV) 収率及び電流効率の結果をまとめたものを Table 2 に 示す。

Table 2 より, 電流効率は硝酸濃度の増加に伴い顕著に増加す ることが確認された。これは, 硝酸濃度の増加に伴い溶液の酸化 力で Ce (IV) が安定に存在しうることが示唆された 7)。しかし, 前述のように硝酸濃度の増大は, 電極の酸化劣化を生じるため, 持続的な電解が行えないと推測された。そのため, 本提案プロセ スでは, Ce (IV) 収率が良好な $1,3 \mathrm{M}$ 硝酸水溶液中での電解酸化 が適切な電解酸化条件であると考えられた。また, 水溶液中にお いて Ce が 4 価から 3 価へ還元する可能性があるため, $3 \mathrm{M}$ 以上 の硝酸水溶液が適していると考えられる。

\section{$3 \cdot 2$ 液体膜分離試験結果}

$3 \cdot 2 \cdot 1$ 溶媒抽出試験本研究が提案したハイブリッド分 離システムにおける液体膜は, 溶媒抽出剤をテフロン膜に含浸す ることで得られる。本研究では, 含浸する抽出剤としてTBPを 用いた。そこで本試験では, 硝酸水溶液中における TBP に対す る Ce (III)， Ce (IV) および Nd (III)の抽出試験を実施した。Fig. 8 に TBP 抽出剤に対する各金属イオンの抽出分配係数の硝酸濃度
Table 2 Assay data of electrolytic oxidation in various $\mathrm{HNO}_{3}$ concentrations.

\begin{tabular}{c|c|c|c}
\hline $\mathrm{HNO}_{3}(\mathrm{M})$ & average current (A) & $\mathrm{Ce}(\mathrm{IV})$ yield (\%) & current efficiency (\%) \\
\hline 0.1 & 0.0251 & 11.8 & 14.1 \\
\hline 1 & 0.0920 & 93.7 & 24.1 \\
\hline 3 & 0.0849 & 94.3 & 35.6 \\
\hline 5 & 0.0703 & 81.0 & 38.3 \\
\hline 7 & 0.0187 & 70.3 & 100 \\
\hline
\end{tabular}

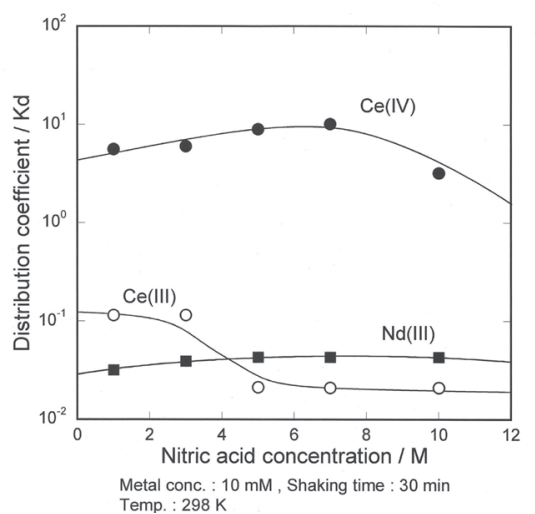

Fig.8 Correlation diagram for $\mathrm{HNO}_{3}$ concentration and behavior of solvent extraction for each elements.

\section{依存性を示す。}

Fig. 8 より，何れの硝酸濃度においても Ce (III)， Nd (III) は, 殆ど抽出されないことが確認された。一方, Ce (IV) は, $7 \mathrm{M}$ 硝 酸水溶液中において抽出分配係数の極大を示し, それ以上の濃度 の硝酸水溶液中では抽出分配係数が低下寸る傾向が確認された。 しかし, 先の試験結果より, 高濃度の硝酸水溶液中では, フロー 型電解セルにおける作用電極の酸化劣化を誘引することが予測さ れる。そのため, 本試験結果から, 3 価の希土類元素と $10^{1} \sim 10^{2}$ 程度の分離係数を示し, 容易に相互分離することが可能である 3 $\mathrm{M}$ 硝酸水溶液での抽出条件が適していると考えられる。

これは, 含リン有機物である TBP の抽出機構に起因するもの と考えられる。含リン有機物等の配位性溶媒は, 金属イオンと硝 酸イオン等の陰イオンとイオン対を生成し, 有機溶媒に抽出され ることが知られている。そのため, Ce (IV) は硝酸イオンとアク ア錯体に似たイオン対を生成し, TBP アアネーションされて抽出

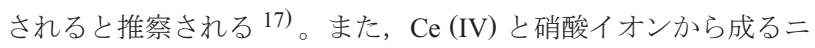
トラ卜錯体は $\mathrm{Ce}$ (III) に対して多様な錯形成挙動をとることは報 告されている ${ }^{18,19)}$ 。そのため, Ce (IV) は硝酸イオンとイオン対 を形成され, 硝酸濃度の増大に伴い抽出分配係数が増加すると推 
察された。一方, Ln (III) は硝酸イオンとの錯体形成能が小さい ため, 殆ど抽出されなかったと考えられた。また, $\mathrm{TBP} \cdot \mathrm{HNO}_{3}$, $\mathrm{TBP} \cdot \mathrm{HNO}_{3} \cdot \mathrm{H}_{2} \mathrm{O}$, (TBP) $\cdot \mathrm{HNO}_{3} \cdot \mathrm{H}_{2} \mathrm{O}$ 等と $\mathrm{Ce}(\mathrm{IV})$ が 内圏 錯体 反応を誘起することも抽出分配係数の増大に寄与したものと推察 される $5,20,21)$ 。

本実験結果から硝酸濃度の低下に伴い, Ce (IV) の抽出分配係 数がわずかに低下することから，TBP に抽出された Ce (IV) は, 希硝酸水溶液により逆抽出が可能であると考えられる。即ち, 本 試験結果は，溶離液に錯化剂等の試薬を用いる必要がないことを 示しており, 分離回収工程における二次廃棄物の拡大を抑制でき るものと考えられる。

$3 \cdot 2 \cdot 2$ 逆抽出試験 溶媒抽出試験の結果から Ce (IV) は, 選択的に抽出されることが示され, 希硝酸水溶液により良好に逆 抽出できることが明らかとなった。そこで, 本研究では, Ce (IV) の逆抽出に最適な希硝酸水溶液を検討するために逆抽出試験を 行った。Fig. 9 に TBP に抽出された Ce (IV)の逆抽出挙動の硝酸 濃度依存性を示す。

Fig. 9 より，TBPに抽出された Ce (IV) は，0.1 M 以下の硝酸水 溶液により $100 \%$ 近く逆抽出可能であることが示唆された。また, $0.1 \mathrm{M}$ 以上の硝酸水溶液では, 逆抽出率が急激に低下し $1 \mathrm{M}$ 硝酸 水溶液では約 $62 \%, 3 \mathrm{M}$ 硝酸水溶液では約 $58 \%$ しか逆抽出され ないことが明らかとなった。これは, 先述の抽出試験結果の抽出 分配係数と良好な一致が見られた。これらの試験結果から, $\mathrm{Ce}$ (IV) の回収には $0.1 \mathrm{M}$ 以下の希薄な硝酸水溶液が適切であること が確認された。本研究では, $\mathrm{Ce}\left(\mathrm{NO}_{3}\right)_{4}$ から $\mathrm{Ce}(\mathrm{OH})_{4}$ への加水 分解等を鑑みて, $\mathrm{Ce}(\mathrm{IV})$ の逆抽出溶液に $0.1 \mathrm{M}$ 硝酸水溶液を用 いることとした。

$3 \cdot 2 \cdot 3$ 液体膜分離試験 これまでの試験結果から, 本提 案システムに適切な抽出・逆抽出条件が明らかとなった。そこで 本研究では，テフロン膜に TBP 抽出剤を含浸させた液体膜を作 成し，液体膜分離試験を行った。本試験では，供給槽側には金 属元素を $10 \mathrm{mM}$ 溶解した $3 \mathrm{M}$ 硝酸水溶液を用い, 回収槽側の逆 抽出液には $0.1 \mathrm{M}$ 硝酸水溶液を用いた。Fig. 10 に各元素の液体 膜分離試験結果を示す。Fig. 10 に示す Partition ratio とは, 供給・ 回収槽内の全金属濃度を 1 としたときの分配比を意味している。

Fig. 10 より Ce (III)， Nd (III)の何れも輸送時間に拘わらず供給 槽と回収槽の割合はほぼ一定であった。これは, 液体膜を介して Ce (III) および Nd (III) イオンの移動が無いことを示している。し かし, $\mathrm{Ce}$ (III) で約 $9 \%, \mathrm{Nd}$ (III) で約 $2 \%$ の回収槽への輸送が確 認された。これは, 溶媒抽出試験の結果と同様に, TBPによる 僅かな抽出作用がある為であると考えられる。一方, Ce (IV) は 輸送時間の進行に伴い徐々に回収槽へ移動していることが示さ れ, 約 130 分後には供給槽・回収槽での濃度割合が逆転した。こ のことから, Ce (IV) は液体膜を介して抽出・逆抽出反応が進行 し, 徐々に回収槽へ移行することが確認された。また, 液体膜に よる抽出反応は, 液液間で行われる溶媒抽出の抽出反応速度と大 きな差がある。これは, 溶媒抽出のようなエマルジョン生成に伴 う高比表面積化が液体膜では困難であることに由来すると考えら れた。そのため, 溶媒抽出の抽出時間よりも多くの反応時間を要 寸ると考えられた。これは, 液体膜を高比表面積化することや液 体膜をカスケード化することで改善することが可能であると考え られる。

\section{$3 \cdot 3$ ハイブリッド分離試験}

本研究では，これまでの試験結果を基にフロー型電解セルと 液体膜分離セルを組み合わせたハイブリッド分離装置を作製し, 本試験装置を用いて Ce と $\mathrm{Nd}$ の分離試験を行った。本試験では,

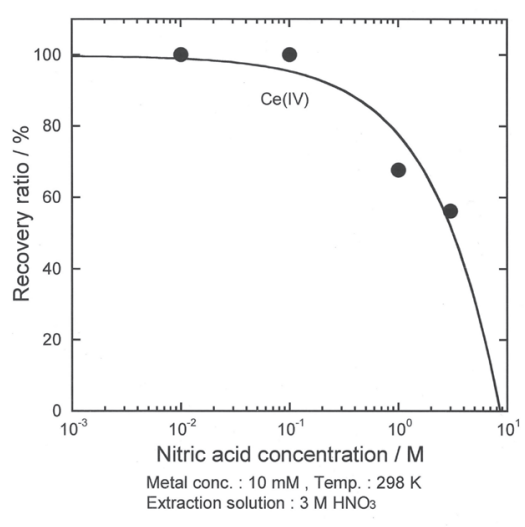

Fig.9 Recovery ratio for various concentrations of $\mathrm{HNO}_{3}$ in back extraction test.

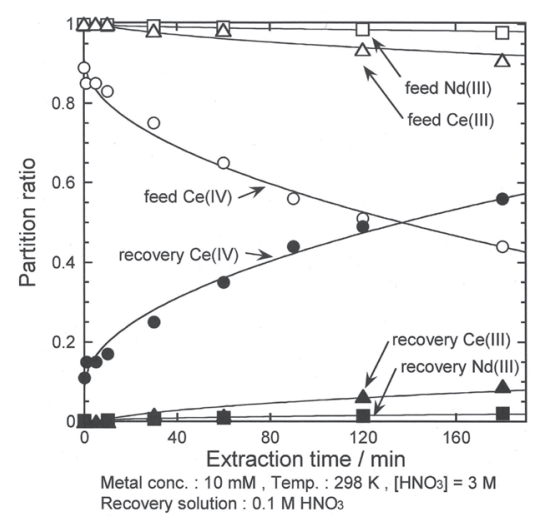

Fig.10 Partition ratio for each elements by liquid membrane separation apparatus.

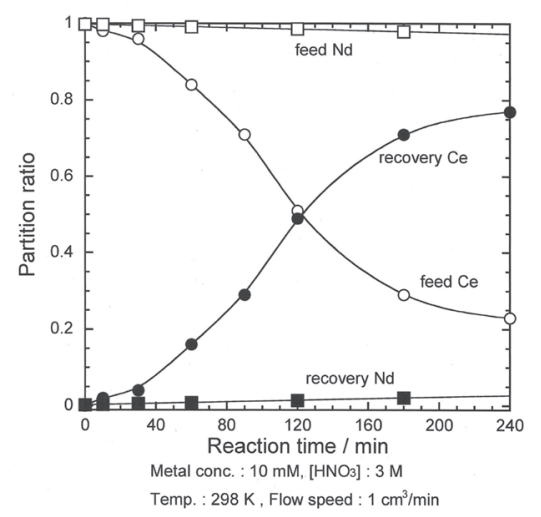

Fig.11 Partition ratio for each elements by hybrid separation system.

$10 \mathrm{mM}$ の Ce (III), Nd (III) をそれぞれ含む $3 \mathrm{M}$ 硝酸水溶液を分 離溶液とし, 流速 $1 \mathrm{~cm}^{3}$ で液体膜分離セルに繋がるフロー型電解 セルへ分離溶液を循環通液した。この時, 電解酸化電位は $1.8 \mathrm{~V}(\mathrm{vs}$. $\mathrm{Ag} / \mathrm{AgCl})$ とした。Fig. 11 にハイブリッド分離試験装置による $\mathrm{Ce}$ と $\mathrm{Nd}$ の分離試験結果を示す。

Fig. 11 より Fig. 10 に示した液体膜分離試験の結果と同様, 約 130 分近傍で供給槽と回収槽の Ce 濃度割合が逆転することが確 認された。この試験結果から供給槽の Ce (III) がフロー型電解セ ルにより Ce (IV) 一電解酸化され, 得られた Ce (IV) が液体膜を 介して抽出・逆抽出反応を生じて速やかに回収槽へ輸送されるこ 
とが示された。先述の液体膜分離試験と比べ， $\mathrm{Nd}$ は同様の輸送 挙動が得られ, Ce は輸送割合の向上が確認された。この要因と して, 液体膜分離装置のみでは, 供給槽内における Ce (IV) 濃度 の減少と共に, 酸化力が低下し, Ce (III) への再還元が予測される。 また，これまでに Ce (IV) は，吸着材や抽出剤等の有機物により 再還元されることが知られている ${ }^{22)}$ 。そのため，ハイブリッド 分離装置のように TBP 等で再還元された Ce (III) もフロー型電解 セルにより定常的に Ce (IV) が生成されるため, 良好に分離が進 行すると考えられた。

これまでの試験結果から, 液体膜分離と電解酸化を同時に行う ハイブリッド分離システムは, 溶液内で不安定な原子価の元素も 分離回収することが可能であることが示唆された。

\section{4. 結言}

本研究で得られた試験結果をまとめると以下の通りである。 1) フロー型電解セルの作用電極であるグラッシーカーボン絨維 は高濃度の硝酸により劣化作用が確認されたため, 低 中濃度の 硝酸水溶液を用いる必要がある。

2) Ceの電解酸化に最も適した条件は電解電位 $1.8 \mathrm{~V}$ ( vs. $\mathrm{Ag} / \mathrm{AgCl})$, 硝酸濃度 $3 \mathrm{M}$ であり，約 $94 \%$ の Ce (IV) 収率が得られた。

3）ハイブリッド分離システムにより, 供給槽内の酸化力低下が 抑制でき, 分配比が約 0.8 程度になり, 約 $80 \%$ の Ce イオンの輸 送が確認された。
4) 本研究の成果から, ハイブリッド分離法によるセリウムの選 択的分離回収が可能となった。

\section{References}

1) T.Fujiwara,Y.Morita: Journal of AESJ, 6 (2007), 358-364.

2) K.Uezu,J.Yamakawa,M.Goto: Jornal of SCEJ, 32 (2006) , 1-5.

3) J.Kobayashi,H.Seto,T.Mori: Journal of RPSJ, 37 (1990) , 157-164.

4) J.Shibata: Journal of RPSJ , 39 (1992), 124-129.

5) R.Kopunec,TH.Ngo Manh: J.Radioanal.Nucl. Chem., 183 (1994) , 181-204

6) Y.Morita,T.Fujiwara,K.Shiraishi et al.:Proc.Int.Conf.on Evaluation of Emerging Nuclear Fuel Systems, Vol. 2 (1995), 1163.

7) T.Sanpei,T.Arai,WEI Y,Y.Kumaya,K.Takeda: Jornal of Ion Exchange, 13 (2002) , 2-9.

8) H.Jianyu,Z.Qingxuan,L.Longjun and T.Baosheng: China Institute of Atomic Energy,P.O.Box 275, Beijing,China,698-702.

9) T.Kano,H.Yanagida; Rare earth osonobusseitoouyo, (Gihodo,Tokyo,1983), p.93.

10) The Electrochemical Society of Japan, Dennkikagaku Binran, (Maruzen,Tokyo,2000), pp. 92-95.

11) S.Kihara,Z. Yoshida,T.Aoyagi: Journal of JSAC, 40 (1991) , 309-323.

12) Y.Takada,S.Uchiyama: "Flow Electrolysis, High Accuracy Basic Analysis", (Academic Pablication,1998), p. 36.

13) S.Kihara,Z. Yoshida,T.Aoyagi: Journal of JSAC, 53 (2004) , 195-205.

14) M.Takagi: Basic Bunnseki Kagaku, (Kagaku Dojin,Tokyo, 2006), pp. 72-73.

15) Hokuto Denko Corporation:Column type flow cell (HX-201, HX-301) instruction.

16) M.Sida: Kagaku Jiten, (Morikita syuppann, Tokyo, 1994) , p. 1407.

17) M.Tanaka; Yobaityusyutsunokagaku, (Kyoritsu,Tokyo,1979), p. 222

18) L.G.Sillen ed; "Stability Constants of Metal-Ion Complex-es", Special Publication No.25, Chem.Soc., London, 1971, p. 34.

19) E.Hogfeldt ed.: "Stability Constants of Metal-Ion Complex-es", Part A,Pergamon Press, 1982, p. 122.

20) J.Zhao,Y.Zuo,D.Li,S.Liu: Journal of Alloys and Compounds, 374 (2004) , 438-441.

21) G.X.Xu: Metallurgy Industry Press,Beijing, 1 (1995), 364

22) T.Arai,Y.Wei,M.Kumagai,T.Sanpei,K.Takeda:Journal of MMIJ, 118 (2002) , 407-412. 